\title{
THE AGRICULTURAL ADVISORY SERVICES AND AKIS SYSTEMS IN ESTONIA, LITHUANIA AND LATVIA - THE COMPARISON STUDY
}

Krystyna VINOHRADNIK, State Higher Vocational School in Tarnow (SHVS), Faculty of Economy, ul. Mickiewicza 8, 33-100 Tarnow, Poland, krystyna.v@wp.pl

The paper based on the results of survey, which have been done under EU project titled „Prospects for Farmers' Support Advisory Services in European AKIS (PRO AKIS)", carried under FP7 in 27 EU countries. The paper contains the analysis of AKIS systems in three European Countries - Estonia, Latvia and Lithuania. The discussed subject is the comparison study of the chosen results of survey of agriculture, the history of creation the agricultural advisory system, and the structures of agricultural advisory and systems of knowledge, information and innovation flows.

The analysed three Baltic countries, in spite of nearly half century of their links by common history and central command of economy policy, after regaining independence, they chosen individual ways to build the AKIS structures. In these processes they used patterns taken from some Western Europe countries, and reached different results. In Estonia, at the moment the AKIS structure is under discussion, because the linkages between AKIS actors are still weak. In Latvia the question is the influence inside AKIS system of three policies - for agriculture, for education and for science - giving as a result the weak cooperation between AKIS actors. In Lithuania, according experts opinion, the AKIS system is working well, and the linkages and cooperation between AKIS actors are rather good.

The general conclusion of discussed subject is, that AKIS system in term of its organisation and structure, is working well only under condition, that the linkages and cooperation between its actors are very strong and integrated.

Keywords: advisory services, agricultural advisory, AKIS system.

\section{INTRODUCTION}

There are several definitions of AKIS. First of all, the main meaning of AKIS abbreviation is: Agricultural Knowledge and Information. One of the formal definition was created by (Rölling and Engel, 1991), who defined AKIS as "a set of agricultural organizations and/or persons, and the links and interactions between them, engaged in generation, transformation, transmission, storage, retrieval, integration, diffusion and utilization of knowledge and information, with the purpose of working synergistically to support decision making, problem solving and innovation in agriculture". Although the system involved actors closely related to agriculture - education, research, advisory, we should notice the changes during the years. So, describing deeply the present meaning of AKIS we should look beyond these sector and consider the presence and role of innovation inside the system.

The European Union countries are not homogenous especially in terms of the characteristics of agriculture, the organizational structure of agricultural advisory or in terms of structure and degree of linkages within the AKIS system. They are characterized by diversity, which is based on the history of political and economic system, and history of organization of advisory services. There are also differences in term of involvement and number of institutions and organisations on the first, second and third sectors in exchange of knowledge, information and innovation within the AKIS systems (Kania et al., 2014).

\section{METHODS OF RESEARCH}

The project was carried on in the period December 2012 till May 2015 and consisted of several work packages. The main goal of WP-3 was the survey of AKIS systems in $27 \mathrm{EU}$ countries. The main tool for survey was questionnaire consisted of seven groups of questions: (1) general information about advisory organisation, (2) human resources and advisory methods, (3) clients and advisory topics, (4) knowledge and cooperation, (5) programming and planning of advisory work, (6) characteristic of farm advisory system, (7) conclusions and recommendations.

The underlying base of statistical data source was Eurostat (data related to 2012) and updated statistics obtained from particular countries during the survey. The research included main advisory bodies of the three sectors - state/public 
institutions, farm-based organisations and NGOs. In the analysis of the obtained data were used the following methods and techniques: (1) well-known descriptive method - used for characteristic of particular countries; (2) the indicator analysis - used for more deep analysis; and (3) the tables, graphs and schemes - used for more clear presentation of survey results.

\section{DISCUSSION}

Analysing the organisational structure and cooperation with AKIS system in three studied Baltic countries, following elements were taken under consideration, which influence the efficiency and the effectiveness of its activity. The basic factors, which determine organisational structure of system, are main characteristics of agriculture - tightly linked with policy, economy and social conditions. The next important element is embeddedness in history and development of agricultural advisory services. And the last, the present system organisation, which dependents on membership of analysed countries in European Union, and requirements connected with membership, which had to be fulfilled before, to create harmony cooperation within EU structures. The decision, to describe the characteristics separately for each of analysed country was taken because of wide differentiation of agriculture characteristics between particular countries as well as individual economy and social policy making by governments of studied countries. The other reason was different ideas and different approach for construction the agricultural advisory structure and different expert and finance support for building the advisory system. As appeared, the simple transfer the proven patterns from countries characterise of high economy level to countries under process of economy transition, appeared not easy, and in some aspect even impossible. Such countries had to find their own way in building the organisational structure and the way of management for agricultural advisory system FAS and the organisational structure for AKIS (Vinohradnik, 2014).

\section{Chosen characteristics of agriculture}

Estonia is a country with 1.3 million people, and it size is $45,2 \mathrm{sq} . \mathrm{km}$. In the rural areas are living $31 \%$ of total number of inhabitants, and the average density is 29 person per sq. km. The Estonian territory characterises of high forest cover, where forest areas prevail over agricultural areas. Nevertheless, agriculture plays a significant role and is one of the major sector and source of income for local people. The share of employment in agriculture is $4.2 \%$ of total employment, and the share of agriculture in GDP is $3.5 \%$. Year by year the number of employee in agriculture is declining. Opposite to EU situation, where agriculture based on family labour, in Estonia, the agriculture is more capitalistic, and it can be observed the trend of growing number of permanent employees working full-time at the farms. The main characteristics of Estonian agriculture are: the concentration of land in large farms (including a significant share of the lease); the declining of the numbers of farms; the increasing number of farms with a status of legal persons. The average farm size in Estonia is 43.1 hectares, but only about $0.2 \%$ of the total number are farms with economic size over 100 ESU. Majority of farms are specialized in the specific production (mainly barley, cattle, sheep and goats, pigs and poultry), which commercial production is $88 \%$ of the total agricultural production. The value of agricultural production in 2012 reached 885.5 million euros. The gross added value of the agricultural sector is nearly 346 million euros (Table 1). The majority of farm owners are elderly people (over 54 years old) without specialized training in agriculture. But there can be observed the trend: the larger size of farm, the younger age and higher level of education of its owner.

Latvia is a country with territory of 64,6 sq. $\mathrm{km}$, where is living 2,1 mill. people. The average density is 32.5 person per sq. $\mathrm{km}$. Latvia is a country with high part of territory covered by forest (45.6\% of total territory). Despite of this fact, agriculture is one of the most important sector in economy -1796.3 ths. ha is covered by agriculture production. The share of agriculture in total number of employees in 2012 was $8.8 \%$, and the share of agriculture in GDP in 2012 was $4.14 \%$. Also, it can be notice growth of GDP per capita, which in 2012 was 10900 euro.

In Latvia, the agricultural production is provided in 83.4 ths. farms. The average size of farm is 21.5 ha. Although, it can be observed the tendency of concentration the arable land, but, there are still small size farms - less than 20 ha $(82 \%$ of total number). The value of production is rather low (in $56 \%$ farms reach less than 2000 euro). Only $1.5 \%$ of farms reached the level of economic value higher than 100 ESU. In Latvian agriculture dominate grain production (wheat and barley), potatoes and apples; in animal production - milk caws, pigs and poultry. It can be observed a growing production of sheep and goats, as well as growing number and area of organic farms.

One third of the farm owners are more 65 years old, and there is only $5.5 \%$ of young farmers (in age less than 35 years). Majority of farms employ family labour (84\%), and $15.6 \%$ farms employ full-time workers.

Lithuania is a country with 3 mill. people, living on a territory of $65.3 \mathrm{sq}$. km. The average density is 46 persons per sq. km. Similar to Estonia and Latvia, Lithuania is a country with significant territory covered by forest, parks and near 3 thousand lakes. But agriculture plays big role in economy and is the main source of income for significant part of employees. The share of employment in agriculture is $8.6 \%$ of total number of employees. The share of agriculture in GDP is $4.0 \%$ (GDP per capita is 9557 euro). The average size of farm is 13.7 ha. Although, in Lithuanian agriculture is $41.6 \%$ of farms, which size cross 100 ha, in fact there are around $20 \%$ of small farms, with economical size less than 4 ESU. There is only $0.4 \%$ of total number of farms, which economical size is more than 100 ESU. Majority of farms specialized in grain production (wheat and barley), sugar beets, cattle and pigs. The value of agricultural production in 2011 accounted for 2401 million and was more than double compared to 2000.

The majority farm owners are in age over 55 years $(54 \%)$, and what more - near $35 \%$ owners crossed 65 years. The young farmers (in age less than 35 years) are only $5.8 \%$. Only $18 \%$ of farmers have professional level of education in agriculture. 
The number of employees in agriculture is decreasing year by year. In majority number of farms there is involved a family labour, but large-size farms also involve full-time hired workers. It can be noticed, that in family farms the factor of full-time workers are higher (12.0 per 100 ha of farmland) than in large-size farms (2.4).

The chosen factors connected with agriculture and the share of this sector in employment and GDP creation in analysed countries are presented in Table 1.

Table 1. Chosen characteristics of Estonian, Latvian and Lithuanian agriculture (2012)

\begin{tabular}{|c|c|c|c|}
\hline Factors & Estonia & Latvia & Lithuania \\
\hline Total number of inhabitants [mill.] & 1.3 & 2.1 & 3.0 \\
\hline Employment in agriculture [\%] & 3.9 & 17.5 & 10.7 \\
\hline Number of fill-time workers per 100 ha of a.l. & 3.1 & 5.1 & 5.4 \\
\hline Territory - total [ths. $\mathrm{km}^{2}$ ] & 45.2 & 64.6 & 65.3 \\
\hline Rural areas [\%] & $\mathrm{n} / \mathrm{a}$ & 29.5 & 46.9 \\
\hline Number of people per 1 sq. $\mathrm{km}$ & 28.8 & 32.5 & 45.9 \\
\hline Number of people in rural areas [\%] & 31.0 & 19.8 & 421 \\
\hline Arable land [ths. ha] & 940.9 & 1796.3 & 2742.6 \\
\hline GDP [ths. $€$ per capita] & 12.7 & 10.9 & 11.0 \\
\hline Agricultural production in GDP [\%] & 3.5 & 4.1 & 3.5 \\
\hline Number of farms [ths.] & 19.6 & 83.4 & 199.9 \\
\hline Average size of farm [ha] & 43.1 & 21.5 & 13.7 \\
\hline $\begin{array}{l}\text { Farms according size }[\%]: \\
<2 \text { ha } \\
2.0-4.9 \text { ha } \\
5.0-19.9 \\
>20.0 \text { ha }\end{array}$ & $\begin{array}{l}19.3 \\
21.7 \\
38.4 \\
27.8\end{array}$ & $\begin{array}{l}15.5 \\
22.1 \\
48.1 \\
17.9\end{array}$ & $\begin{array}{l}17.3 \\
42.4 \\
30.7 \\
10.6\end{array}$ \\
\hline Farms $>100$ ESU [\% of total] & 0.4 & 1.5 & 0.1 \\
\hline Organic farms [\% of a.1.] & 13.4 & 3.5 & 1.1 \\
\hline Number of organic farms [in ths.] & 1.4 & 3.6 & 64.5 \\
\hline Value of agricultural production [mill. $€$ ] & 885.5 & 2401.0 & 2401.0 \\
\hline Number of producer groups & $\mathrm{n} / \mathrm{a}$ & 44 & 1 \\
\hline
\end{tabular}

Source: Eurostat 2012, country reports of Estonia, Latvia and Lithuania, 2013

\section{History and development of agricultural advisory services}

The systems and structures of advisory services in EU countries are deep embedded in history, economy and social relations. In the study is showed the short history of agricultural advisory development in analysed countries.

In Estonia, during the period of Soviet Union - central planning of economy and dominated state ownership in agriculture - the advisory services were duty and part of tasks of state research institutes (specialised in agriculture production and veterinary) and its experimental stations. In term of organisation - advisory units were localised in regional administrative offices, and for this reason advisory agents were rather administrative officers than agricultural advisors. Parallel to re-organisation of economy, in agriculture appeared necessity to introduce new agricultural advisory services to fulfil the farmers' needs and expectations.

In practice, in Estonia, the history of agricultural advisory services has its initial point in 1989. First three years, the initiative to establish the new advisory system was created and developed. Then, the decision to build agricultural advisory system oriented for client was undertaken. In the end of the last century, there was undertaken the initiative for building the free market for advisory services, and parallel was provided the privatisation and reconstruction of public sector. The last phase, in 2003-2013, focuses on building the FAS (Farm Advisory System) and improving the effectiveness of advisory services.

In general, in building of Estonian advisory system can be pointed-out three phases: the first one - is strongly connected with privatisation of land, creation the family farms and free farmers' associations. In that period, the good example can be the Federation of Farmers, a first organisation in Estonia, which established independent agricultural advisory system, consists of: regional advisory units being the farmer union ownership; education centres under farmer units; and the Education and Agricultural Advisory Centre in Jäneda. The second phase, in fact it was the period of experiments, in which the trials of implementation the foreign models of advisory systems were undertaken (with some experts and finance support coming from abroad). No one project occurred well fitted to local conditions. In the results, the Estonian government decided to fully finance advisory services delivered by the Education and Agricultural Advisory Centre in Jäneda and give partly finance support for advisory services provided by farmers' unions. Very soon, occurred, that advisory services didn't reply for large scale farmers' needs, and at the same time that kind of farmers couldn't afford for advisory services, because too high fee. The next government decision was to subsidise this part of advisory services, which have influence for improvement into production. Such approach was strictly connected with certification program for advisors. As the result of education program, near 200 advisors received certificates giving them rights to be advisors. The third phase is connected with the period of Estonia entrance into EU structures and necessity to fit the Estonian legislation rights and administration to the terms of EU agreement, and to create new institutional structure of advisory capable to support in implementation of CAP. In fact, these challenges opened advisory market for free lancers and 
pressed government to re-build advisory system and support its structure. As the result, there were following acts: creation the group of experts for re-building the system, creation the coordinative centre for information transfer, building the information centres on the county levels and rural information on the village levels. After evaluation, the organisational changes were undertaken, and at first the Coordination Centre for FAS was connected with Estonian Agriculture and Trade Chamber, but after short time the Chamber left this organization and joined the Foundation for Rural Development - the reason of that act was improvement in effectiveness of advisory services. In the opinion of Ministry of Agriculture the present system is working well, although there is necessity to extent advisory services in a very narrow specialisations, but they have not enough of high educated experts in that range of services.

Each of these phases is recognised as a key period in development of Estonian agricultural advisory system.

In Latvia, after regaining its independence in 1990, parallel to process of political, economic and social transition, the process of building the AKIS system was provided. Looking at the history, particular institutions and organisations within the AKIS have their own long history. Some of them were established in 19 century and survived even Soviet Union governance, maintaining relationships, taking care of traditions and accumulating knowledge. However, the specific conditions, created by the process of post-communist privatization, the introduction of a market economy and the restructuring of agricultural production, compelled state authorities to re-organize the AKIS system. Responding to the needs of new farmers, many of whom did not have even basic agricultural knowledge, the Ministry of Agriculture and the Latvian Farmers Federation formed in 1991 the Latvian Agricultural Advisory Centre and Education (with advisory network across the country). At the same time there were developed the new tasks for research, connected with agricultural reform, new technologies and cereal production.

The mile stone in Latvian AKIS became the preparation process for accession to EU, in the second part of $1990^{\text {th }}$. Under this process particular activity was focus on adapting the Latvian legislation to the EU requirements, which brought a significant change relating to both agricultural producers and advisory system. In 2004 the Latvian Centre for Education and Rural Advisory (LRATC) was created, as a company Ltd., and partly self-financing institution. LRATC was establish under strong influence of Ministry of Agriculture, and for this reason the Ministry contracts the services connected with implementation of specific programs of rural development.

Parallel to LRATC activity, in the AKIS system the number and role of many other private firms was growing-up, e.g. producers of means for agricultural production, agricultural co-operatives or freelancers in specific services. Recently, it can be observed a tendency to create the trans-sectorial or trans-disciplinary platforms inside the AKIS. The good example can be: Centre for Knowledge Transfer, Cluster for Industrial Innovation and Platform for Food Technology. The platforms are a form of new innovative policy, where scientists and practitioners can exchange knowledge and information and where in fact is a mutual education. Thanks the platforms activity, and in less formal net of links with practitioners, scientists and researchers receive knowledge and information about practitioners' needs and expectations.

In Lithuania, before the $2^{\text {nd }}$ World War, the agricultural advisory were delivered by Agricultural Chamber and Central Union of Milk Processors Pienocentras. But, the main subject of advices were connected with development in milk processing. In the period of Soviet Union economy, the advisory system practically didn't exist. There were no individual farmers, and the system of central planning covered all needs of large-scale, state (sovchoz) and so call cooperative farms (kolchoz).

When Lithuania regained its independence, the large-scale farms were resolved, and many individual persons received agricultural land. Soon appeared, that they have any experience and any knowledge to work effectively in their farms. The Lithuanian Farmers' Union and Association of Agricultural Processors in co-operation with Ministry of Agriculture funded Lithuanian Agricultural Advisory Service (LAAS). In cooperation with Danish Centre for Agricultural Advisory, under PHARE Program, the final structure of LAAS, with divisions across the country, was created. The advisory services create near $90 \%$ of budget revenues, and it is expected the LAAS will become self-financing institution, soon. Around half of total LAAS employees are the field advisors, and one third has professional university level of education, the others are technicians. The main goal of LAAS is a support for farmers for implementation the EU requirements in environment protection, animal welfare, good agricultural practice and cross-compliance. In 2006 the Association for Rural Development and Business Consulting (AVDBC) was created, and one of its roles are also advisory services in a narrow, specific subjects.

Today, in a structure of agricultural advisory are three main groups of advisory organisations: private, public/state: Lithuanian Agricultural Advisory Service (LAAS), and farmer based organisation: Lithuanian Agricultural Chamber (CARL). Ministry of Agriculture accredited 44 advisors from both these organisations and few private advisory organisations, which can provide advisory services. Some of private organisation joined Association for Advisory in Rural and Business Development (ARDBA). The member of that Association can be only professional organisations, having experience in agricultural advisory. Framers have in disposal also advisors representing trade companies selling technical equipment, fertilizers and plant protection products.

\section{Contemporary organisation of AKIS system}

In general, comprehensive and well-functioning system of education and advisory (in terms of knowledge transfer and advisory services) is seen as an important determinant of the development of agriculture and rural areas. In addition, the efficiency of the operation is expressed through close scientific ties with all partners of the system, internal collaboration and just-in-time transfer of knowledge, which is actually the driving force for innovation. Knowledge and Information System Agricultural (AKIS) presents the exchange of knowledge and support services between many 
different actors from the first, second, and third sector in rural areas. AKIS provides to farmers the knowledge and shows the network of connections around innovation in agriculture.

When analyzing the AKIS in the 27 member states of the EU, it can be notice that the AKIS is not unified. In fact, every country has built its own system, which is based on local regulations, the form of ownership of research institutions and advisory organizations, educational structure, funding sources, the characteristics of agriculture, farms and farm owners - their needs and expectations, but also the necessity to implement the CAP and the local agricultural policy. However, there are some similarities, to compare and evaluate them and give conclusions is not easy.

In Estonia, the AKIS system is built with research organizations, advisory and education, and managed by the government through sectoral agricultural policy. A significant role in the dissemination of information and the functioning of the AKIS has played the Estonian Rural Development Plan (ERDP) 2007-2013. Thanks to ERDP farmers, producers, processors and owners of private forests received a set of knowledge and possibilities for participation in their operations (Korpa and Tisenkopfs, 2013). Today, Estonian AKIS consists of the following five main components (Fig. 1):

(1) Partners managing and coordinating: the Ministry of Agriculture, the Agricultural Agency for Registration and Information (ARIB), the Estonian Board of Agriculture, the National Rural Areas Network, and the Estonian Rural Development Foundation. Their role in AKIS system is described below.

The Ministry of Agriculture is responsible for the AKIS as a whole and managing the agricultural advisory and rural development institutions (except the universities). In relation to the advisory, the role of the Ministry comes down to: determining the rights and financial framework for the operation of advisory system; creating conditions for the functioning of advisory centres; ERDP management activities; support in planning of advisory and training activities; developing a framework for advisory services and tools to implement cross-compliance; evaluate the functioning of FAS. The Agricultural Agency for Registration and Information (ARIB) was created originally to implementing the SAPARD Program. The Estonian Board of Agriculture is a government council of experts, funding from the state budget, but plays a marginal function in AKIS. The National Rural Areas Network established in 2008 as Rural Economy Research Centre, which aims at the gradual development of rural areas through bottom-up initiatives. Network membership is not mandatory, but the members are organizations involved in rural development, for example: Chamber of Agriculture and Commerce, various rural associations, Association of Private Forest Owners, various NGOs, Universities, Local Action Groups. The Estonian Rural Development Foundation (RDF), founded in 1993. The main task of the Foundation is to provide for the banks a guarantee of repayment of loans obtained by farmers and rural entrepreneurs and to support specific programs aimed at economic development in rural areas. Since the beginning of 2010, RDF coordinates the system of advisory services in agriculture and rural areas (including FAS).

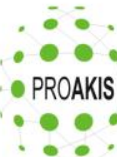

\section{Prospects for Farmers' Support: Advisory Services in European AKIS (PRO AKIS)}

ESTONIA
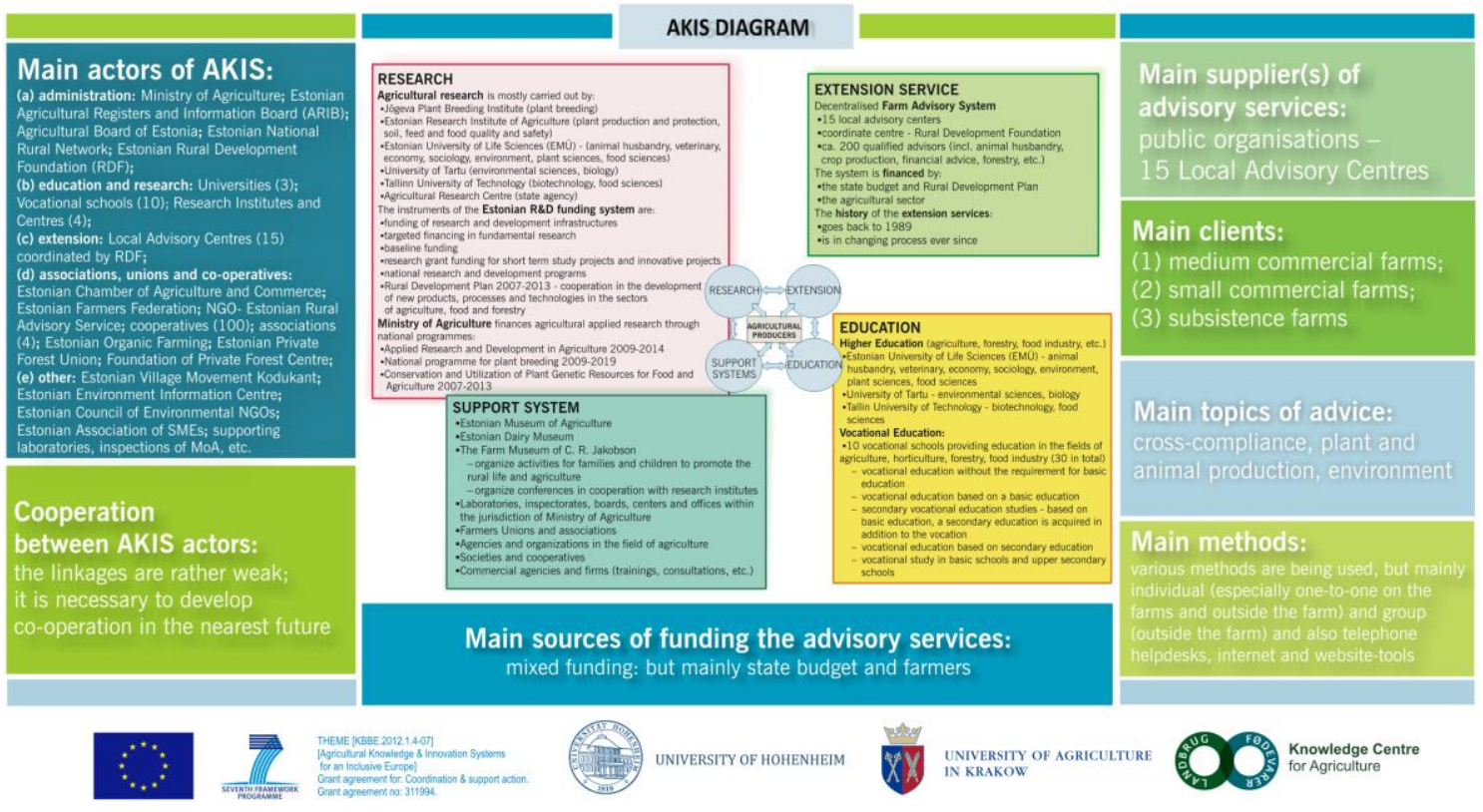

Knowledge Centre
for Agriculture

Figure 1. AKIS system in Estonia

Source: Korpa, Tisenkopfs 2014 (general scheme), Tworzyk (poster)

(2) The partners involved in the advisory - two groups: (a) decentralized agricultural advisory system, which consists of 15 local advisory centres (initially coordinated by the Estonian Chamber of Agriculture and Commerce, and 
then from January 2010 by the Foundation for Rural Development, the role of advisory centres is to conduct consulting individual and providing information to local producers and farmers; (b) private independent advisors and consultants from Estonia and abroad offering advisory services for farmers and agricultural producers.

(3) The partners involved in the research and education - three groups: (a) studies conducted by the Estonian University of Life Sciences, University of Tartu, Tallinn University of Technology, Institute of Plant Breeding in Jõlgeva, Estonian Research Institute of Agriculture, Agricultural Research Centre, Research Centre for Rural Farms; (b) agricultural education conducted in 10 vocational schools (along with a program of continuing education for adults) and two universities in Tartu and Tallinn; (c) Rural Development Foundation, which awards scholarships for students of agriculture.

(4) Associations, unions and cooperatives: (a) the various types of associations, unions and cooperatives of farmers, and producers of one industry, e.g. dairy, breeding, etc.; (b) the Estonian Chamber of Agriculture and Commerce uniting producers and their associations and the companies conducting services for the agricultural sector. The Chamber supports the work of local producers and processors and trade on internal and external markets, and represents its members in all kinds of national and supranational structures; (c) the Estonian Farmers Federation; (d) the Estonian Rural Advisory Service, acting as an NGO; (e) agricultural cooperatives; (f) the various associations (producers, breeders, etc.); (g) unions of farmers, young farmers, Central Union of Estonian Farmers, etc.; (h) the Foundation for Organic Production; (i) the Association of Private Forest Owners (an umbrella organization of forest owners' associations). Advisory services for forest owners are coordinated by the Centre for Private Forests Foundation.

(5) Other partners in the Estonian AKIS: e.g. Estonian Environment Council (NGO); Estonian Association of Small and Medium Enterprises; Country Kodukant Movement.

In Latvia, there is no separate policy dedicated to AKIS system. The legislation rights can be found in few policies: for science, for education, for innovations and for agriculture (including advisory services). The traditional core of AKIS system are sub-systems: research, education and consulting, and particular agencies AKIS subject to relevant various ministers and for that reason the coordination of system is not operational. Both, national policy and agricultural policy pay special attention to education, knowledge and agricultural skills (producers and advisors), and establish these tasks one of the four priorities (Š̄umane et al., 2013).

As already mentioned, Latvian AKIS consists of three basic components (organizations and research institutions, education and consulting), which are largely subordinated to the three policies - agricultural, scientific and educational, but also we can see all sorts of formal and informal education network and innovation flow, which often combine knowledge of individual actors in the system with the practice of agriculture and processing and industries sectors. The main role in the system AKIS play four categories actors: public and private sector, farmers and agricultural organizations (Fig. 2).
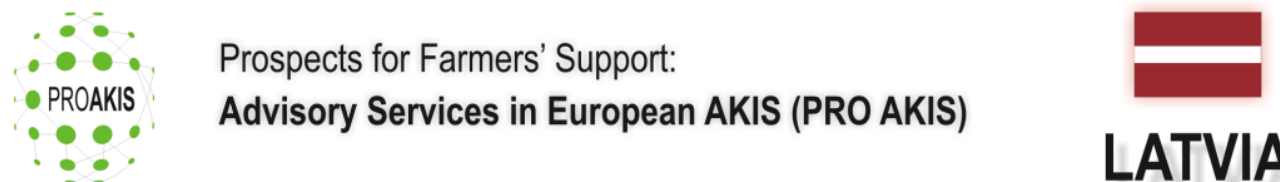

\section{LATVIA}
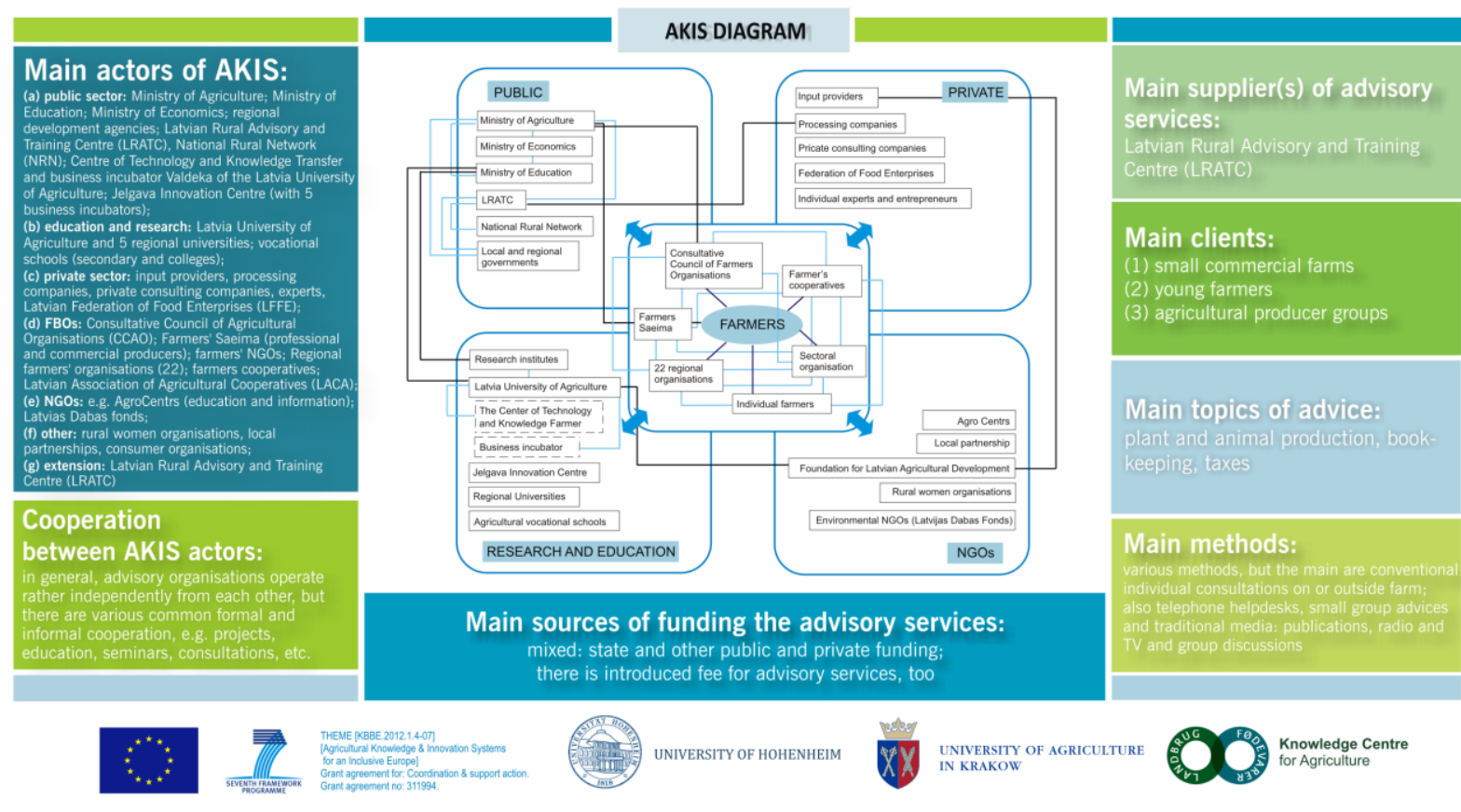

Figure 2. AKIS system in Latvia

Source: Šūmane, Grīviņ̌̌, Tisenkopfs 2014 (general scheme), Tworzyk (poster)

Public sector: At the national level there are three ministries directly involved in the management of AKIS system. The Ministry of Agriculture is responsible for agricultural policy and policy towards rural, agricultural education at the 
university level, agricultural research and agricultural extension, and supports to producers' organizations. The Ministry of Education is responsible for science policy and education (with the exception of agricultural universities subordinate to the Ministry of Agriculture). Responsibility for innovation and the development of rural areas and links with science and industry has been delegated to the Ministry of Economy. At the regional level - five regional development agencies are responsible for territorial planning and coordinating the regional development as well as for the acquisition and allocation of financial resources to initiate and participate in projects implementation of agricultural innovation and dissemination of knowledge. Local governments are responsible for the co-financing of consulting for local development led by the Latvian Centre for Rural Education and Consulting (LRATC). LRATC is the largest consulting organization in Latvia, covering advisory network throughout the country.

The National Network of Rural Areas (NRN) is a platform for exchange knowledge and information between the actors representing rural areas and agriculture. The network organizes training and information seminars, to exchange knowledge and information at the local and transnational level, disseminates information, research initiatives and programs of research. In the last few years, there erased a number of new organizations dedicated to knowledge transfer and innovation, and also to facilitate the transfer of results of research, and to cooperate with science and industry, e.g. the Centre of Knowledge and Technology Transfer, incubators of business, innovation centres.

The sector of research and education is represented by 40 research institutions. The main role plays Latvian University of Agriculture (including its eight faculties), four research institutes, three laboratories, experimental farm, Knowledge Transfer Centre and Lifelong Learning. All these institutions are the sources of knowledge for producers, experts of advisory, organizers of trainings, producers' associations and individual farmers. However, agricultural research, in principle, are decentralized and scattered, weak communication between research disciplines and research organizations, making it difficult to coordinate the investigations. Similarly, between researchers and farmers is extremely limited link, because of insufficient level of infrastructure development, which creates problems in conducting research applications. Researchers conduct investigations and create new technologies, but few of them are disseminating these technologies. To consolidate resources, to coordinate researches (to strengthen the links between research institutes and researchers with practitioners), to create improvement in infrastructure for transfer the results of research, the National Centre for Research for Agricultural and Food Resources has been established.

Agricultural education sector in the Latvian AKIS represents 10 professional schools (where teachers provide also professional advisory services for farmers) and one Agricultural University (with 9000 students). The other five regional Universities also have a consulting activity serving advices for farmers and local communities. Currently, a reform in secondary education is going on, and its aim, among others, is reduction the number of secondary level professional agricultural schools.

Inside the structure of the Latvian AKIS are also private organizations. Farmers, mostly owners of large farms and agricultural cooperatives, in principle, are benefit from technology producers and input distributors of foreign companies operating in Latvia. These companies conduct marketing advisory, organize demonstrations in the farm and demonstration and education through product placement. Moreover, on the market of advisory services can be seen other, new Latvian private companies, conducting general and specialized advisory.

The processing companies in the AKIS system play dual role - they are recipients of knowledge and information, as well as providers of knowledge. The Latvian Federation of Food Industry (LFFE) focuses businesses, professional associations and research institutes. Its aim is to promote the development of the food industry, promotion of Latvian products in local market and increase competitiveness in transnational markets. Recently, LFFE engaged in a process to develop standards for vocational education and training for food industry workers.

An important source of information for agricultural producers are experts, highly determined to find contacts and cooperation with farmers, many of them lead more private or individual consulting based on short-term contracts with customers than through institutional structure. In the opinion of many farmers this form of consulting is the most preferable, because it meets their needs and is more easily available.

In addition, in the structure of the AKIS are also farmers' organizations. In Latvia can be seen all sorts of farmer organizations to disseminate knowledge and leading consulting and at the same time lobbying agricultural education, research and influencing appropriate agricultural policy. The best-known organization working in that field is the Consultative Council of Agricultural Organisations (CCAO). Other non-governmental organizations, are organized in the branch-form and are engaged mainly in services, exchange and creation of new knowledge useful for the industry. Similarly, cooperative organizations (the four largest), which are producers of inputs, are also involved in the activities of dissemination the information and knew knowledge. Some of them have a wide network of information abroad, where it is easier to collect the latest knowledge. These organizations operate under the umbrella of the Latvian Agricultural Cooperatives Association (LACA), which facilitates the exchange of information between its members and offers consulting and vocational training.

Another important actors in the AKIS system are farmers, who are both creators and providers of knowledge. Many of them offer paid or free consulting, resulting from their knowledge and experience, conduct demonstrations in cooperation (or without) with research institutes, organize practical training on their farms (often in cooperation with LRATC).

In the structure of AKIS there are also other types of non-agricultural, non-governmental organizations having different functions, acting for rural development, e.g. foundations, unions and women's associations, local partnerships, consumer organizations, etc., which associate many actors with different professional qualifications.

Lithuanian AKIS consists of two main groups - institutions and organisations at national level, and agricultural advisory service - public, private, and education and research sector (Fig. 3). The public institutions at the national level are: 
the Ministry of Finance and the Ministry of Agriculture, which play a role of supervisor for Centre of Information and Business in Rural Areas, Centre for carry on the LEADER Program and Methodology in Agricultural Education, and the Lithuanian Network of Rural Areas. In AKIS system, on the national level are also private processor companies, producers and dealers of technical equipment, and agricultural producers - farmers and firms (Ramanauskas and Zukovskis, 2013).

The agricultural advisory service represents three pillars: (1) public sector and farmer organisations, e.g. the Lithuanian Agricultural Advisory Service (LAAS) and Agricultural Chamber (CARL); (2) research and education institutions, e.g. the Aleksandras Stulginskis University, the Lithuanian University of Health, few other institutes and research centres, the Centre of Science and Innovations "Valley Nemunas" and secondary professional agricultural schools; (3) private organisations and agricultural advisory association, e.g. 14 Associations for Rural Development and Business Consulting (ARDBA); NGOs, e.g. Association of Rural Districts, LAG; private processors, dealers of technical equipment and agricultural producers (companies Ltd., public organisations, private entrepreneurs, free lancers for agricultural advisory).

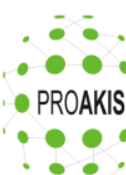

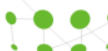

Prospects for Farmers' Support:

Advisory Services in European AKIS (PRO AKIS)
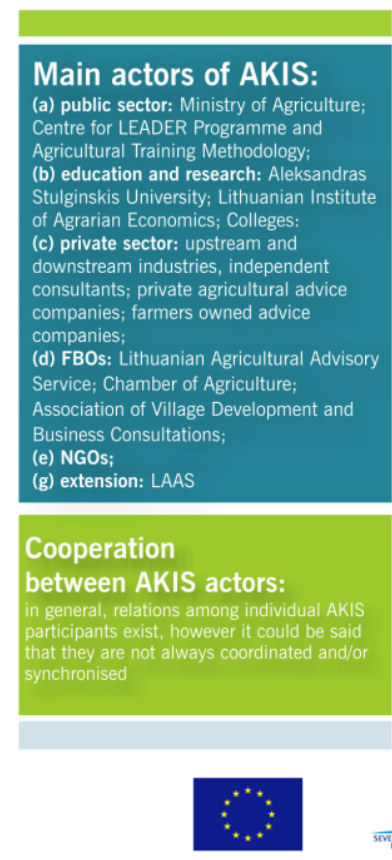
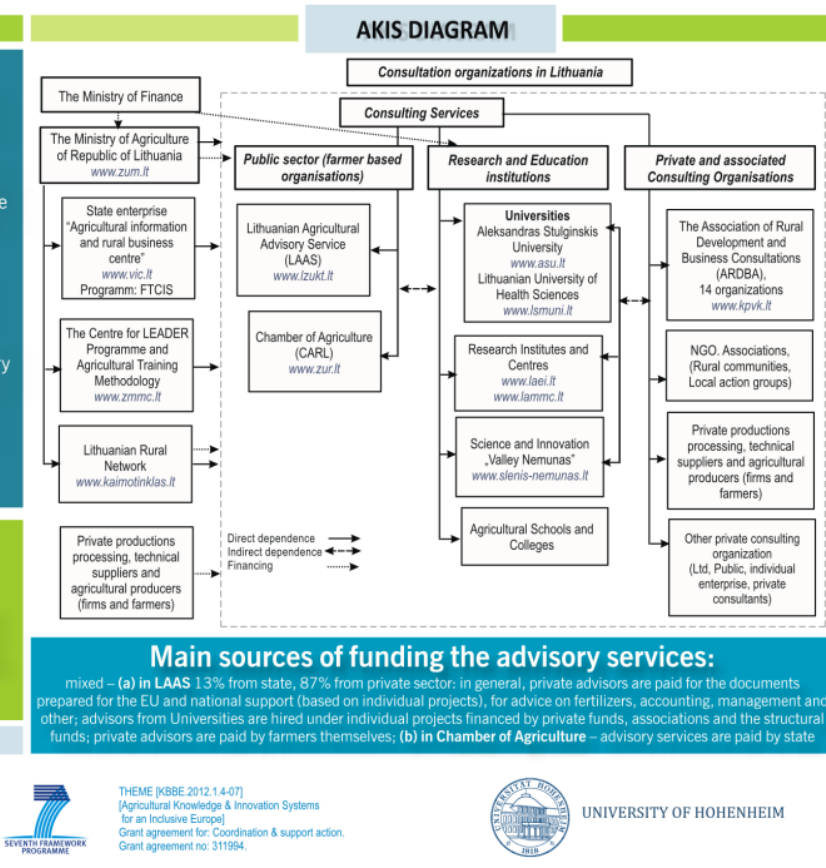

\section{AKIS DIAGRAM}

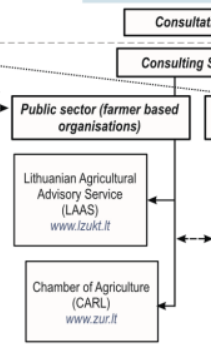

Consulting Services
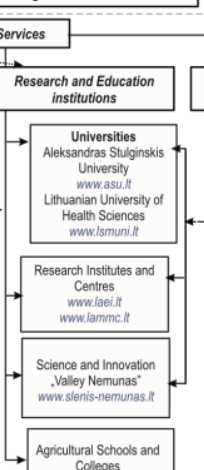

Collegens
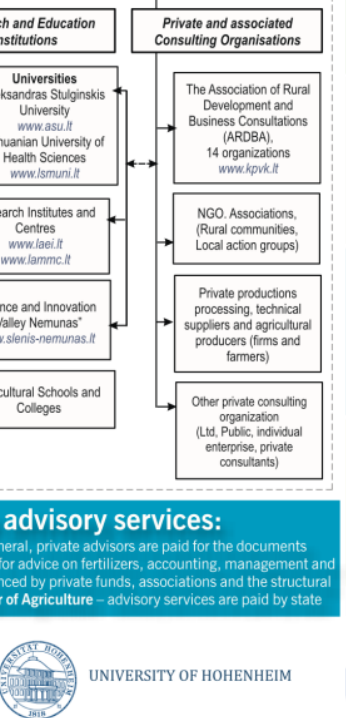

LITHUANIA

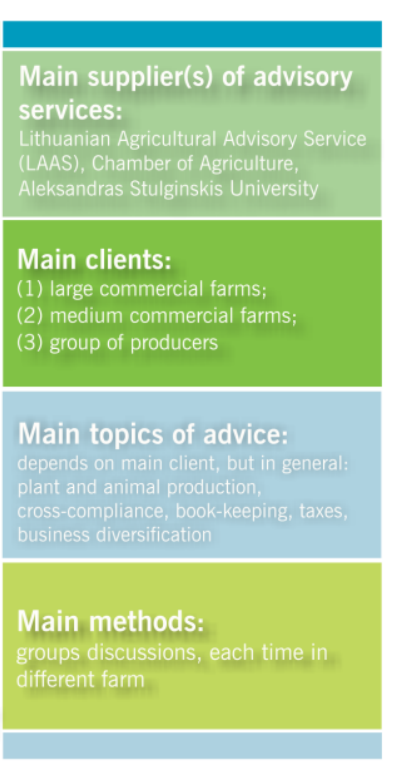

UNIVERSTTY OF AGRICULTURE

IN KRAKOW

Figure 3. AKIS system in Lithuania

Source: Ramanauskas, Zukovskis 2014 (general scheme), Tworzyk (poster)

\section{CONCLUSIONS}

Although analysed three Baltic countries, for nearly half a century were linked by common history and associated with a central command economy policy, the organisational structures of knowledge, information and innovations transfer (AKIS) in these countries show quite substantial differentiation. After regaining independence, each of these countries has chosen its own path to build a market economy, creating new agricultural economy and structures of the system of knowledge and agricultural information flow, drawing on models taken from Western Europe countries. These choices not always corresponded to local conditions, hence the need to introduce many changes in the organizational structure, internal links and relations and policy of funding the research and advisory services. The study analysis provides the following conclusions:

In Estonia the linkages between AKIS actors are still weak and there is necessity to impose effort to improve their cooperation. The lesson taken from trials of implementation different foreign AKIS models shows that there is no simple transfer even good model from a country with high level of economy and implement it into completely different situation in term of economical and sociological conditions. But these experiences brought significant effect, they became a solid base to develop own Estonian model. At the moment of finalising the research, in Estonia was going-on the discussion how to modify present system. It concentrated mainly on: strengthen the collaboration between scientists, agricultural advisors and agricultural producers; availability and way of dissemination of reliable and accurate scientific information; integration of research with advisors and producers expectations. 
In Latvia, the efficiency of AKIS system is still not satisfying. There was noticed some difficulties being the result of lack the common policy - in practice the influence on AKIS have three policies: for agriculture, for education and for science, which are crating separately by three different government sectors. Such a situation is not conducive to internal linkages within the structure of the transfer of knowledge, innovation and agricultural information. But, the first changes can be observed, already. Recently, three ministers, responsible for creation these three policies, in co-operation with practitioners, have started to work on improvement and coordination the activity of all parts of AKIS structure. The National Research Centre for Agriculture and Food Resources was created and professional agricultural schools moved to Centres of Professional Education. But the question how to absorb the valuable, but fragmented knowledge, produced by not coordinated research is still waiting to be solved. There is opinion that the EIP approach for co-creation of new knowledge and innovation for farmers will bring positive effects.

In Lithuania, the country experts evaluate the AKIS system as well-functioning. Inside its structure are 40 public and private organisations providing advisory services for farmers. Farmers have choice and in fact, they decide which advisory organisation would like to ask for advice, and they are rather satisfied of such situation. The linkages between AKIS actors are rather good, and there is co-operation between them. But observing the advisory service market, the number and activity of newcomers (private research and advisory organisations, and NGOs) is growing, and it is necessity to undertake the discussion on AKIS structure and on improvement in system co-ordination.

In general, the system (its structure and organisation) of knowledge, information and innovation transfer is working well only under condition, when all its parts are very strong linked each other and integrated in activity - starting from farmers (owners or farm managers), who are the main subject of advisory work, through advisory service providers, professional and university education, research institutes, institutions and organisations surrounding agriculture (within them also such, which support financially specific enterprises), and ending on the policy creators (government and parliament).

\section{REFERENCES}

1. Rolling, N. G., Engel, P. G. H. 1991. IT from a knowledge system perspective: concepts and issues. In: Kuiper, D. and Roling, N.G. (eds). The edited proceedings of the European Seminar on Knowledge Management and Information Technology. Wageningen: Agricultural University, pp. 8-20.

2. Kania, J., Vinohradnik, K., Knierim, A. (eds) 2014. AKIS in the EU: WP 3 - The Inventory, Final Report, v.1 - Summary Findings, www.proakis.eu/

3. Korpa, V., Tisenkopfs, T. 2013. Estonia Country Report, Baltic Studies Centre, Riga.

4. Ramanauskas, J., Zukovskis, J. 2013. Lithuania Country Report, Aleksandras Stulginskis University, Kaunas.

5. Šūmane, S., Grīviņ̌š, M., Tisenkopfs, T. 2013. Latvia Country Report, Baltic Studies Centre, Riga.

6. Vinohradnik, K. 2014. Systemy doradztwa rolniczego w Estonii, Litwie i Łotwie (The Systems of Advisory Services in Estonia, Latvia and Lithuania). Wies i Doradztwo (Countryside and Extension), Vol. 1, Iss. 77, pp. 4-11. MSDR Krakow. (In Polish)

7. Tworzyk, A. 2014. Set of posters produced for PRO AKIS Project. 